\title{
Examining farmers markets' usage of social media: An investigation of a farmers market Facebook page
}

\author{
Yue Cui* \\ Michigan State University
}

Submitted February 26, 2014 / Revised May 15 and 16, June 30, and July 24, 2014 / Accepted

August 12, 2014 / Published online December 1, 2014

Citation: Cui, Y. (2014). Examining farmers markets' usage of social media: An investigation of a farmers market Facebook page. Journal of Agriculture, Food Systems, and Community Development, 5(1), 87-103.

http://dx.doi.org/10.5304/jafscd.2014.051.008

Copyright (C) 2014 by New Leaf Associates, Inc.

\begin{abstract}
Social media are transforming communication between organizations and their audiences, and even changing the organizations themselves. Social media's low cost and low requirements for technical skills needed to both use and maintain an online presence allow small businesses with limited marketing budgets to use the same marketing strategies as bigger businesses with large marketing budgets. In addition, social media provides businesses direct and interactive ways to reach out and retain customers. This case study analyzes Cedar Park Farmers Market (CPFM)'s use of its Facebook page. Using Facebook Graph API Explorer, we extracted data regarding posts and fans of CPFM's Facebook page since the page was
\end{abstract}

* Dr. Yue Cui, Assistant Professor, Department of Community Sustainability, Michigan State University; 130 Natural Resource Building; East Lansing, Michigan 48824 USA; +1-517-897-0550; cuiyue.msu@gmail.com created. We then examined the data to explore the social networks, including farmers market organizers, vendors, and customers, within CPFM's Facebook page and how the market used its Facebook page, by looking at the Facebook page layout, composition of fans, post intensity, post ownership, media type, and degree of engagement. We found that (1) the market organizers, customers, vendors, and local communities were all engaged with the CPFM Facebook page; (2) the CPFM used Facebook as a marketing platform to publish timely information (e.g., available products or upcoming events) and to reach and retain customers and vendors; and (3) the CPFM's Facebook page functioned as a cybersocial hub to connect and engage the local community.

\section{Keywords}

Facebook, farmers market, social media, marketing, social hub 


\section{Introduction}

As public concern about the quality of food in the conventional and commercial food system grows, so does the enthusiasm for local foods (Hinrichs, Gillespie, \& Feenstra, 2004). The momentum behind the local food movement has grown in recent years with rising support for, and awareness of, local farmers markets, making them increasingly popular destinations among food shoppers (Kaufman, 2004). The past two decades in particular have seen a phenomenal growth rate in the number of markets in the United States; the number increased by 364 percent from 1996 to 2013, totaling 8,144 markets (USDA, n.d.a).

The growth in the number of farmers markets also means that market organizers face more intense competition for both customers (demand) and vendors (supply). Therefore appropriate marketing strategies to recruit and retain both customers and vendors are key to the success of a farmers market. For example, an extension study from Nevada (Cowee, Curtis, \& Gatzke, 2009) found that farmers market organizers have traditionally reached their customers and vendors using oneway, passive communication approaches, such as word of mouth, local television, radio, newspaper, roadside signs, and websites (Cowee et al., 2009). With the emergence of social media, communication methods between markets, vendors, and customers have fundamentally changed as increasing numbers of farmers markets adopt social media. This study is motivated by the need to understand how farmers markets are using Facebook as one avenue to establish a social media presence, and how Facebook allows farmers markets to interact and engage with customers, vendors, and communities.

The inherent attributes of the farmers market make social media an ideal marketing tool. Farmers market's products and events change from week to week, making timeliness more important in marketing. The interactions within farmers markets are not limited to customers and the market; they are among the market organizers, customers, and vendors. Most farmers markets are resource-limited and cannot afford traditional unidirectional marketing strategies (e.g., radio, television, newspaper). Social media require little in the way of special skills to build social media sites, and the cost to use and maintain a social media site is relatively low (Jussila, Kärkkäinen, \& Aramo-Immonen, 2014). These attributes make social media affordable marketing platforms for small businesses like farmers markets.

In 2013, the USDA Farmers Market Directory Update form was expanded to allow market managers to list their social media tools, such as Facebook and Twitter, as part of their market communication tools (in addition to their websites). This revealed that Facebook is already a major form of social media that farmers markets use, as over 2,000 markets provided a Facebook link, far more than any other form of social media, such as Twitter, Pinterest, FourSquare, or Instagram (USDA, n.d.b).

Unlike for its personal profiles, Facebook allows people to view posts on an organization's Timeline (previously called the Wall) without logging into their account. The posts on the Facebook page, the number of fans a page has, and the ways in which people interact on Facebook (e.g., likes, comments and shares) are accessible at no cost. This provides researchers an opportunity to observe who, how, and what people and/or businesses communicate on Facebook pages in a natural environment without influencing their behavior Using the Cedar Park Farmers Market's Facebook page (CPFM, n.d.) as an example, this study collected all the posts and daily fan counts from the date its Facebook page was created until December 22, 2013. By observing people talking and interacting on CPFM's Facebook page, this study found that farmers markets' Facebook pages serve multiple purposes. The Facebook page is a marketing platform for farmers market's organizers and vendors to publish timely information about market operations, available products, and upcoming events, as well as an effective way of reaching and retaining customers and vendors through multilateral interaction and engagement. The CPFM's Facebook pages also function as a social hub to connect vendors, customers, and the local community, and as a public bulletin board to share resources, ideas, and interests and to provide forums to educate, promote healthy living, support agriculture, and resolve conflicts. 


\section{Value of Farmers Market Participation in Social Media}

There are many conceptions of what constitutes a farmers market. Since 2000, researchers have offered different definitions for farmers markets: "specialist markets trading in 'locally produced' products, and food must be sold by the producers" (Holloway \& Kneafsey, 2000, p. 286); "recurrent markets at fixed locations where farm products are sold by farmers themselves" (Brown, 2001, p. 658); "a common facility or area where multiple farmers/growers gather on a regular recurring basis to sell a variety of fresh fruits, vegetables and other farm products directly to customers" (Payne, 2002, p. 173); and public spaces "where people come to buy locally or regionally produced goods and engage in community life on a regular basis (Francis \& Griffith, 2011, p. 262). Although these authors describe farmers markets differently, the definitions have common features, such as direct marketing, the characteristic of being recurring, fresh and healthy products, locally grown, and community linkages. These concepts of farmers markets also reflect the major functions of a farmers market: the provision of staple foods (La Trobe, 2001) and, more marginally, the consumption of ancillary or amenity items (Hergesheimer \& Kennedy, 2010; Smithers, Lamarche, \& Joseph, 2008). As a direct marketing channel, vendors and customers interact face-to-face in a farmers market. Most of the studies regarding the social network in a farmers market setting describe this social network as being composed of customers, vendors, and the community (Abel, Thomson, \& Maretzki, 1999; Alia, Freedman, Brandt, \& Browne, 2013; Gerbasi, 2006). Each of these groups participates in the farmers market and draws value from it.

In terms of market participation, factors driving customers to visit farmers markets include procuring local, fresh and healthy foods (Andreatta \& Wickliffe, 2002; Guthrie, Guthrie, Lawson, \& Cameron, 2006; Hinrichs et al., 2004; Hunt, 2007; Sadler, Clark, \& Gilliland, 2013; Sanderson, Gertler, Martz, \& Mahabir, 2005) and enjoying the shopping experience (Feagan \& Morris, 2009; Guthrie et al., 2006; La Trobe, 2001; McGrath, Sherry, \& Heisley, 1993; Sadler et al., 2013). Ven- dors have both economic and social reasons for participating in farmers markets (Hinrichs et al., 2004; Lyson, Gillespie, \& Hilchey, 1995). Griffin and Frongillo (2003) indicated that farmers markets act as a marketing channel for vendors as well as a means to increase profit margin. In addition, scholars (Hunt, 2007; Morris \& Buller, 2003) have found that vendors report a sense of contribution to the local community by participating in farmers markets. Aside from the major function of providing staple foods, the farmers market is a material and symbolic space for local communities. It provides a sense of security and connects surrounding communities (Hergesheimer \& Kennedy, 2010; Madison, 2002). The social benefits of farmers markets for local communities include increased social vitality (Conner, Colasanti, Ross, \& Smalley, 2010), reinforcement of local values (Cummings, Kora, \& Murray, 1999), and provision of space to promote social activity and human capital development (Brown \& Miller, 2008; Farmer, Chancellor, Gooding, Shubowitz, \& Bryant, 2011). The resurgence of farmers markets exemplifies the city landscape as a space for leisure, relaxation, and community development (Farmer et al., 2011; Oberholtzer \& Grow, 2003).

\section{Social Media, Facebook, and Their Applications for Organizations}

"Social networking" refers to the use of social media to turn communication into interactive, multidirectional exchanges that create engagement and build relationships and communities (Boyd \& Ellison, 2007). Social networking services such as Facebook and Twitter are primarily used to connect communities of individuals who share similar interests. People use social media to share and discuss their daily experiences, socialize with friends, receive information, and entertain themselves (He, Zha, \& Li, 2013; Kaplan \& Haenlein, 2010;

Keckley \& Hoffmann, 2010). In business applications, social media allow organizations to connect with many more people more frequently than using phone calls, emails, or meetings allows (Luke, 2009). The cost for development and support of social media has fallen drastically and the technical skills required to use social media are low and easily 
learned. Using social media creates opportunities for organizations to communicate directly, quickly, and frequently with individual customers, and to disseminate information about products and services (Palmer \& Koenig-Lewis, 2009). As an increasing number of users connect on social networks, social media are becoming increasingly used by the Internet audience (Khan \& Boehmer, 2013). One of the major social media platforms in the United States, Facebook, was launched on February 4, 2004, and has become one of the most popular websites in history (Parsons, 2013; Sage, 2013). Facebook provides various features including profiles, pages, groups, advertising, and email (Facebook, n.d.a). It enables individual users to present themselves in a profile and gather friends who can interact on each others' pages. For businesses, it enables individuals and other organizations to affiliate themselves as fans and to interact with the business. Once a user is a fan of a business on Facebook, that user can share information about that particular business with their friends. Facebook allows organizations to use pages at no cost, which is a significant advantage for low-cost businesses like farmers markets.

Facebook pages have a fixed format and design theme for all users. Users personalize their page by inputting their own content including a profile picture, photos, Timeline posts, and links. This structured format, in addition to having a low cost and low requirement for technical skills, means that small businesses on Facebook have the same marketing opportunities as larger businesses (Khan \& Boehmer, 2013). Social media use public posts and comments to generate high interactivity. This transparent interactivity describes and prescribes the manner in which conversational interaction as an iterative process leads to jointly produced meaning (Rafaeli \& Sudweeks, 1997). In a marketing setting, another concept close to interactivity is engagement, which is "the intensity of an individual's participation in and connection with an organization's offerings and/or organizational activities, which either the customer or the organization initiate" (Vivek, Beatty, \& Morgan, 2012, p. 4). On Facebook pages, this engagement can be expressed through behaviors such as commenting on posts, "liking" them, and sharing information
(Khan \& Boehmer, 2013). Studies on the social media phenomena started with individuals' behavior (Sage, 2013). Recently, scholars have steered their research to look at what businesses and organizations are actually doing within social media. So far, most of this organization-related social media research focuses on large companies, such as airlines (Leung, Schuckert, \& Yeung, 2013), and chain stores (He et al., 2013). Sufficient research has not been done on small businesses, even though prior studies claim that small businesses have the same competitive "position" as big companies on social media such as Facebook. In addition to the lack of research on small businesses, no research has been conducted on how farmers markets use Facebook.

\section{Research Questions}

Research Question 1: In physical space, the social network of a farmers market comprises the market organizer, vendors, customers, and the local community. This study will examine how the roles physically played in farmers markets communicate and engage on a farmers market's Facebook page, and whether the social network of Facebook reflects the actual social atmosphere of farmers markets.

Research Question 2: How do farmers markets use their Facebook pages? Given that the major function of farmers markets is the provisioning of staple foods, this study will investigate how a farmers market uses Facebook as a marketing platform to advertise available products and upcoming events, and the relationship management strategies employed by a farmers market on Facebook to engage customers, vendors, and the local community. In addition, this study will investigate a farmers market's marginal functions such acting as a social hub through Facebook pages.

\section{Data and Methods}

To select a case study market, we focused on finding an urban market that supported at least 50 vendors and that had a reasonably mature Facebook presence (more than 2 years). We also sought a market that operated year-round. This assured substantial numbers of participants and content to inform the study. This study used Cedar Park 
Farmers Market's Facebook page (CPFM, n.d.) as a case study to identify how farmers markets use Facebook as a marketing platform and social hub. CPFM is located in the city of Cedar Park, near Austin, Texas. It is organized under F2M Texas, a nonprofit corporation that provides Central Texas farmers and ranchers with direct-marketing opportunities. CPFM provides central Texans with a wide variety of locally produced foods in convenient locations (CPFM, n.d.). It is a year-round market open Saturdays from 9 AM to 1 PM. CPFM created its Facebook page on February 2, 2010. As a business page, CPFM's Facebook Timeline posts can be viewed by anyone. We used the Facebook Graph API (Cross, 2011) to crawl all feeds posted on CPFM's Facebook page from February 2, 2010, to December 22, 2013. The post objects related to this study include post owner (FROM), creation time, media type, text message, and interactions such as likes, comments, and shares. In addition, the number of fans of the CPFM Facebook page was counted every day starting with its creation.

Four classifications of posts were used in this study to understand Facebook usage: post owner, media type, posting intention, and posting intensity (the posts by the days of week). We used information on post owners (CPFM, customer, vendor, and others, including businesses and organizations) to respond to research question 1 . The post owner was identified by the name and categories in the "FROM" variable. Businesses and organizations provided their business category beside their name. Vendors were identified by the business name. The vendors list provided by CPFM in the "About" page was used as reference to separate the vendors from all organization posts. Customers were identified by individual "profile" users without a business category. In addition to post owners, the media type, posting intentions, posting intensities, and degree of engagement were used to answer research question 2 . The media type was classified as Text-Only (status), Link, Photo, and Video through the post type attribute. Posting intentions were used to understand the usage of Facebook pages in many social media studies. For example, Cvijikj and Michahelles (2011) categorized posts for marketing purposes by post intention as sug- gestions and requests, affect expression, sharing, information inquiry, complaints and criticism, gratitude, or praise. Leung et al. (2013) classified the Facebook posts of three budget airlines into six categories. They include promotions, sharing, announcement, invite engagement, celebrities at destination, and user involvement. The posting intentions classification was used in this study to understand how the farmers market uses Facebook. The posts were manually coded into five categories:

(1) Announcement: CPFM used Facebook to announce information, including market operation, vendor information, events, etc. (e.g., Posts 1-4):

Post $^{1}$ 1:

CPFM: Local Business FRESH, NEVER FROZEN chicken this week plus new batch of lamb, fresh farm eggs and pork for their CPFM customers.

Post 2:

CPFM: VENDOR NAME will add Sweet Potato Pie to her goodies this Saturday.

Post 3:

CPFM: HIGH SCHOOL FFA is selling transplants of tomatoes and a variety of peppers. The proceeds go to pay for trips and attendance at judging contests at various colleges...

Post 4:

Vendor: Thanks to all who come to the markets to support our community and to help the victims of the recent wildfires... we will be giving a percentage of our sales tomorrow to buy much needed items for the families along with donations collected by the market...come by and see us SFC Farmers' Market

Customer: I guess I need to give you my order!... See you in the morning!

Vendor: Thanks...I also have some yummy pb oat flax dog cookies for donations to BUSINESS NAME.

\footnotetext{
1 Persons' names, business names, website names, and URL links have been removed for privacy purposes. Posts have been copied as posted, so any misspellings, slang and/or abbreviations are in the original posts.
} 
(2) Inviting Engagement: Post owners attempt to invite others to become involved in discussion by asking questions to solicit responses from vendors, customers, and the community (e.g., Post 5):

Post 5:

CPFM: A shopper complained to a farmer last week about bug holes in some of the produce at the market. I want to make sure you all understand that if it your produce lacks holes, you should complain because that means pesticides are being used! NUF SAID, right?

Customer 1: It's pretty sad when people don't know what real food is supposed to look like. Customer 2: I think I brought home a small worm of some kind and a wasp. I was pretty thrilled! Must be good stuff if they thought it was yummy enough to live in.

Customer 3: aww, i remember when i saw my first bug in my farmer's market food, $i$ was scared too, but now im get excited when $i$ see them! lol Customer 4: I bought a basket of tomatoes, only one had a worm in it! I was actually wondering if one should bring that to the farmer's attention? Not because I'm mad that there's a worm, but more to make them aware?...

Customer 5: But now I know it's a sign of a bealthy environment and to cut the bad out. Vendor 1: As a farmer we try to protect our vegetables from bugs by using free range chickens to control the bug population and by covering the leafy greens when the bugs are more than the chickens can bandle. I actually like the bug boles as proof of spray and chemical free farming practices.

Vendor 2: We always say, "better BUGS than chemicals!"

(3) Market Experience: The farmers market, vendors, and customers share their experiences of the market day on Facebook (e.g., Post 6):

Post 6:

CPFM: Thanks to every last one of you who braved these Texas elements to get your food. This market has really evolved into a close little community of people who care about their families and themselves... and others.

Customer 1: Beautiful. I get such the most pleasant feeling of peace and community at the market. I had stuffed portabella mushrooms for lunch w/ my family. Thank you all for your contributions!

Customer 2: I visited the market for the first time today. I really enjoyed it. I felt like a kid in a candy store!!

Customer 3: How crayy that today felt warmer than last week? Wonderful market day!

Customer 4: Local food deserves to be supported year round! Farming doesn't stop for the weather and neither do the bills! Thanks to everyone of the vendors for braving the weather.

Customer 5: Local food is awesome and so are all the vendors!!! Love it when we get to make the market and sad when our schedule probibits it! Customer 6: I loooooove the market! BTW, any word on whether the Tomato Guy will be coming back and how he's healing up?

Customer 7: The market has become part of the week that I look. forward to now. Love chatting with the vendors that truly care about what they are providing to the community. Looking forward to summer fruit...

CPFM: Tomato guy, VENDOR NAME1 is still healing and hopes to return this spring. It has been about 6 weeks since I last spoke with bim. Good reminder to call and check on bim! Also fruit...strawberries are coming in the next couple of weeks from VENDOR NAME2. Did you know that VENDOR NAME3 had asparagas?

(4) Inquiry Market Information: Customers, vendors, and others ask questions regarding market operations through posts (e.g., Posts 7-8):

Post 7:

Customer 1: Does anyone every have emu or ostrich eggs?

Customer 2: *ever not every

CPFM: Nope. Sorry.

Customer 3: This place in BUSINESS

NAME has them - URL LINK, just a few minutes east of Hutto 
Post 8:

Customer: We missed VENDOR NAME

this weekend. Please tell me they will be back!

CPFM: VENDOR NAME did a benefit on

Friday to raise money for the Louisana Coast.

They hail from Lovisana and came here after the

burricane. Good for them, hub? We are proud to

have them as a part of our market! They will be

back this week.

Customer: yea!

Vendor: Thank you, we are sooo very proud to be a part of this grand market. Can't wait to be back!

(5) Share: external link sharing, photo and video sharing, and profile updates for any content other than market experience (e.g., Post 9):

Post 9:

CPFM: Should we ALL be on the WEBSITE $N A M E$ ? There are a few things we can learn from these little buggers...URL LINK

Post 10:

Others: 20 acres are currently burning in Leander between Bagdad and 183. Please keep those in your thoughts.

Next, we conducted a posting intensity analysis based on the post's creation time. Due to the farmers market's recurring nature, we grouped posts by day of the week (Monday to Sunday) and measured the intensity of different days. To understand the relationship between post activity and market operation day, the posts were further grouped to Pre-market Days (Thursday and Friday), Market Days (Saturday), After-market Days (Sunday and Monday), and Other Days (Tuesday and Wednesday). We also examined fan interactions and engagement on CPFM's Facebook page. Facebook Insights (Facebook, n.d.b) provides precise metrics for the reach and engagement of posts. However, due to privacy issues, only the Facebook page owner (CPFM) was able to access the Insights details. The available interaction and engagement measures for public Facebook posts are likes, comments, shares, and number of fans, which are widely used by scholars (Cvijikj, Spiegler, \& Michahelles, 2011). In this study, the degree of engagement for CPFM's Facebook posts were measured using Equation (1) below:

$$
\begin{aligned}
& \text { Degree of engagement }=(\# \text { likes }+\# \text { comments } \\
& + \text { \# shares }) / \text { total fans at that day }
\end{aligned}
$$

\section{Results and Discussion}

As of December 22, 2013, there were 6,369 posts on CPFM's Facebook Timeline; since the creation of CPFM's Facebook page, it has accumulated 8,265 fans. Figure 1 shows that the number of posts and fans grew steadily over time.

\section{Header and Profile of the CPFM Facebook Page}

The header and profile on top of the Facebook Timeline give visitors the first impression of a business page. Figure 2 is a screenshot of CPFM's Facebook page header.

CPFM used a banner (cover) image to display products, e.g., fresh vegetables, to attract
Figure 1. Cumulative Distribution of Number of Posts and Number of Fans on CFPM's Facebook Page (February 4, 2012December 22, 2013)

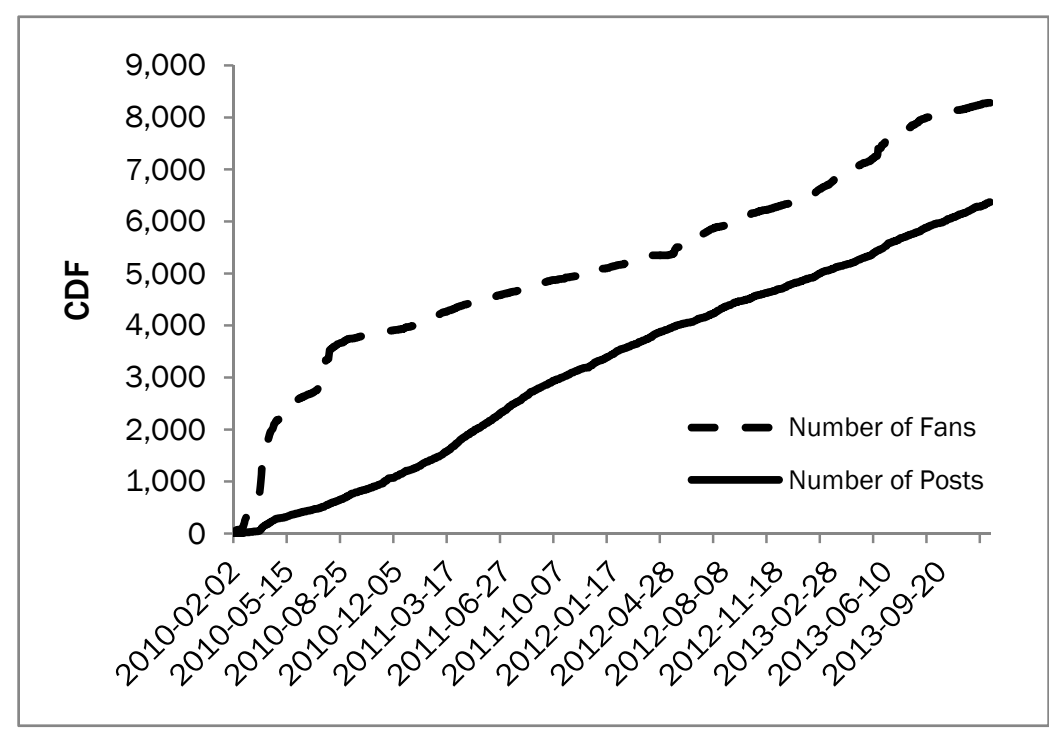


Figure 2. Header of Cedar Park Farmers Market's Facebook Page (Captured on December 22, 2013)

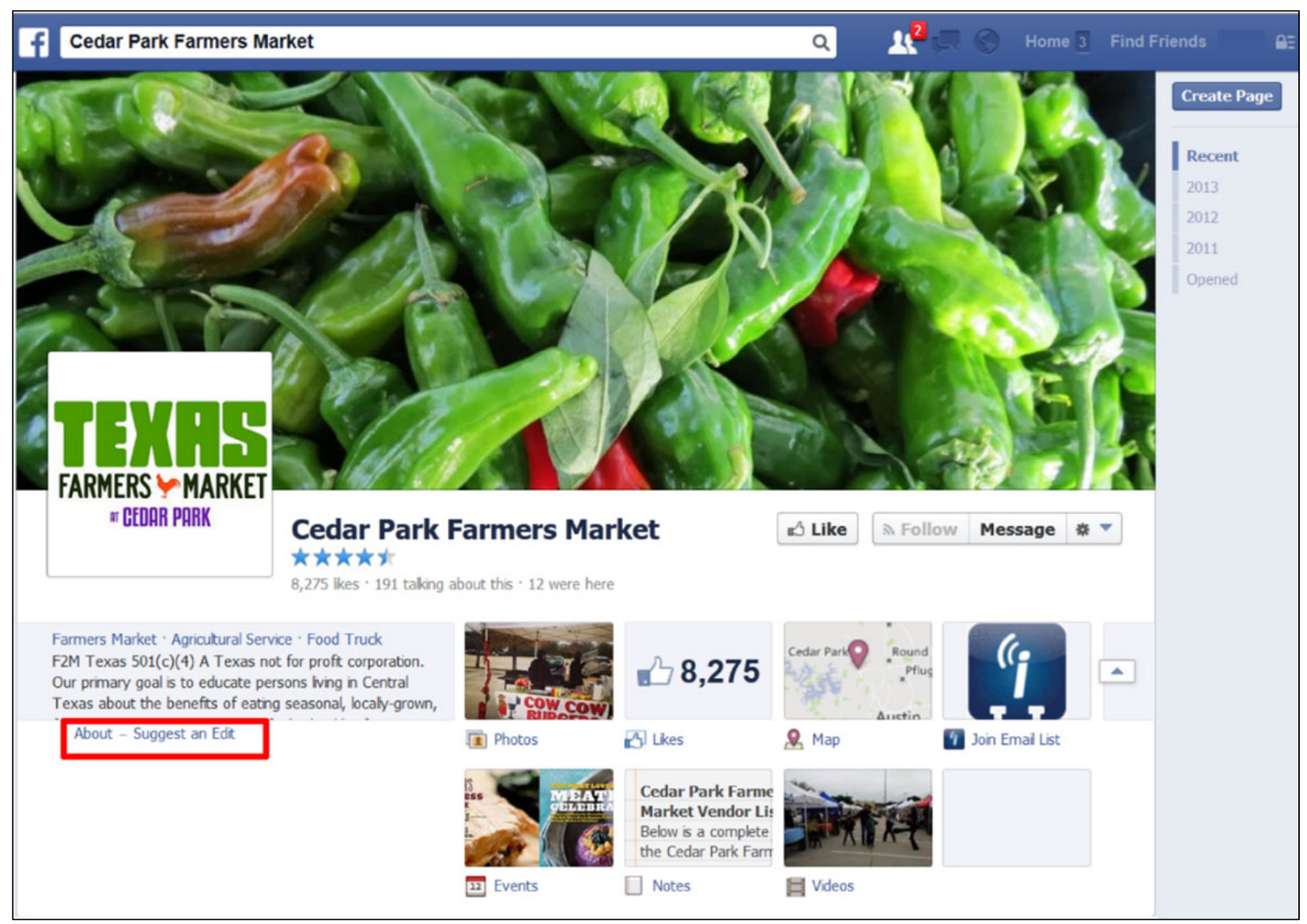

customers and advertise what is available at the market. The header also highlighted CPFM's logo, photos, videos, number of page likes (fans), a map of its actual location, events, notes, and the option to join the email list. There was an About link to provide more detailed information about CPFM. The screenshot of the About section is shown in Figure 3.

The About page displayed business location, phone number, email, website, operation hours, and parking information, as well as displaying CPFM's mission statement. It also listed market vendors, which is valuable to both customers and vendors. The header actually depicted the directory and fixed operation information for the market and served as the "brick and mortar" of the CPFM operation.

\section{CPFM's Social Network on Facebook}

To explore CPFM's cyber social network and understand who is active on CPFM's Facebook, we categorized posts by owners (CPFM, customers, vendors, others). Figure $4 \mathrm{a}$ is the distribution of posts by owners. Among all the messages on the Timeline, about 60 percent were posted by the CPFM. The other two-fifths were posted by vendors ( 25 percent), customers (13 percent), and others (2 percent). In terms of the composition of the CPFM's fans, customers made up 95 percent, while the remaining 5 percent of the fans were identified as organizations. A similar method was used to classify the "organization fans" by the business category in their profiles, as businesses (e.g., 365 Things To Do In Austin), nonprofit organizations (e.g., Texas Organic Farmers and Gardeners Association), governments (e.g., City of Cedar Park), and other famers markets (e.g., 
Figure 3. About Page of Cedar Park Farmers Market's Facebook (Captured December 22, 2013)

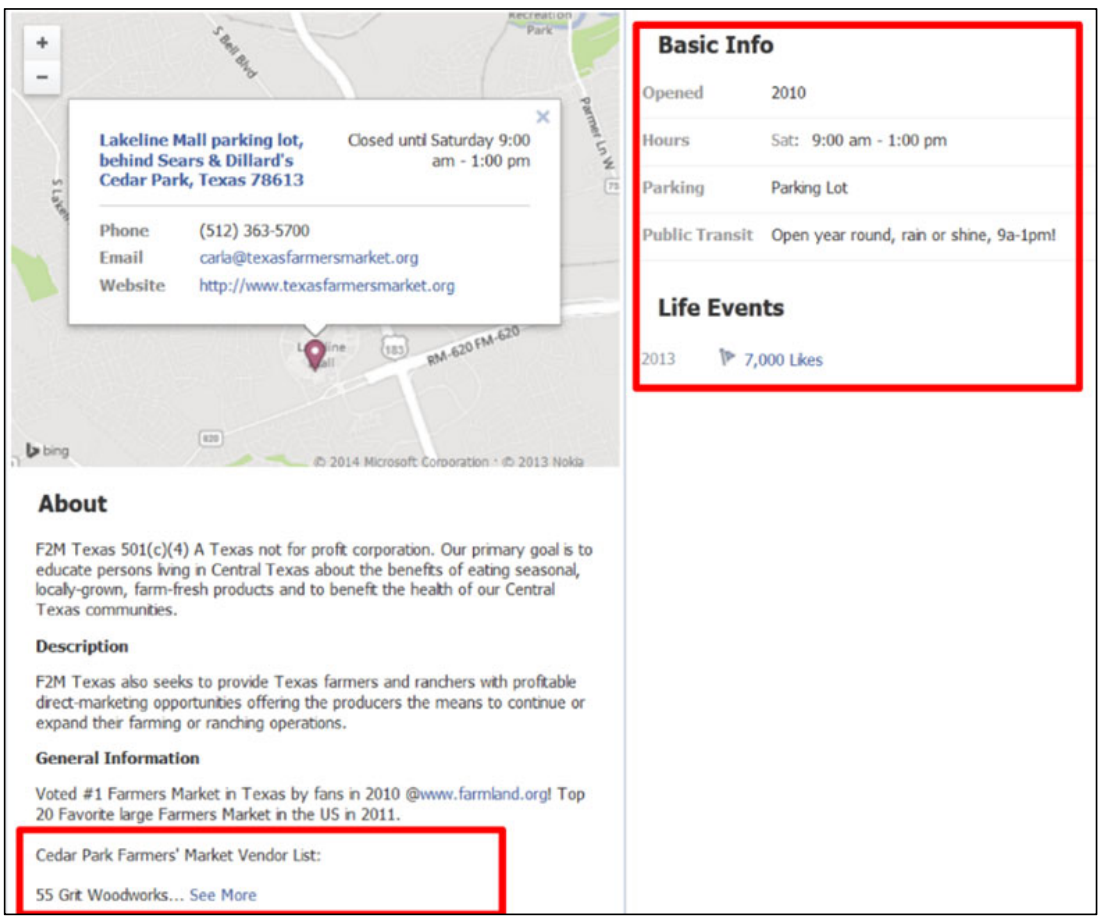

2006). In addition, Figure $4 b$ displays the others members in the farmers markets' network: local communities, government, and organizations that have not been examined by previous studies. These two figures display the structure of the cyber social network of the CPFM and provide evidence that the Facebook page is a hub to gather customers, vendors, and communities.

\section{The Usage Pattern of CPFM's Facebook Page}

We measured usage of the CPFM Facebook page by post owner, posting intention, media type, posting intensity, and degree of engagement. Table 1 lists the distribution of posts by posting intention and post
Mueller Farmers Market). The distribution of organization fans is shown in Figure 4b. It is no surprise that customers and vendors were the major players in the farmers market's social network, as this is consistent with findings from other studies in physical space (Alia et al., 2013; Gerbasi, owner. In general, about two thirds of the posts were Announcements, while five percent were Inquiring Market Information. The rest of the posting intentions are as follows: Inviting Engagement (11.5 percent), Market Experience (14.0 percent), and Share (11.8 percent).

Figure 4. Composition of the Social Network for Cedar Park Farmers Market's Facebook Page

(a) Distribution of Posts by Post Owner

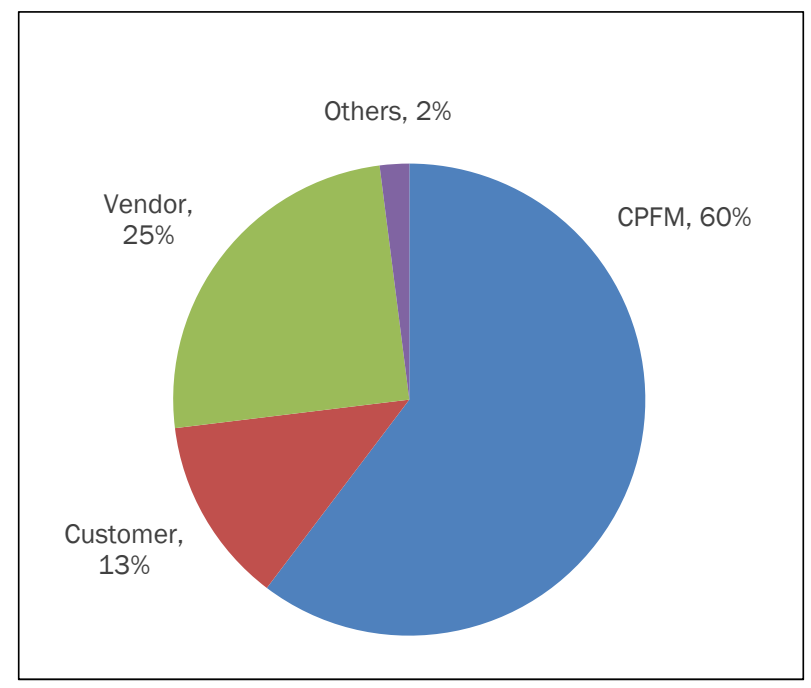

(b) Distribution of Organization Fans $(N=8,265)$

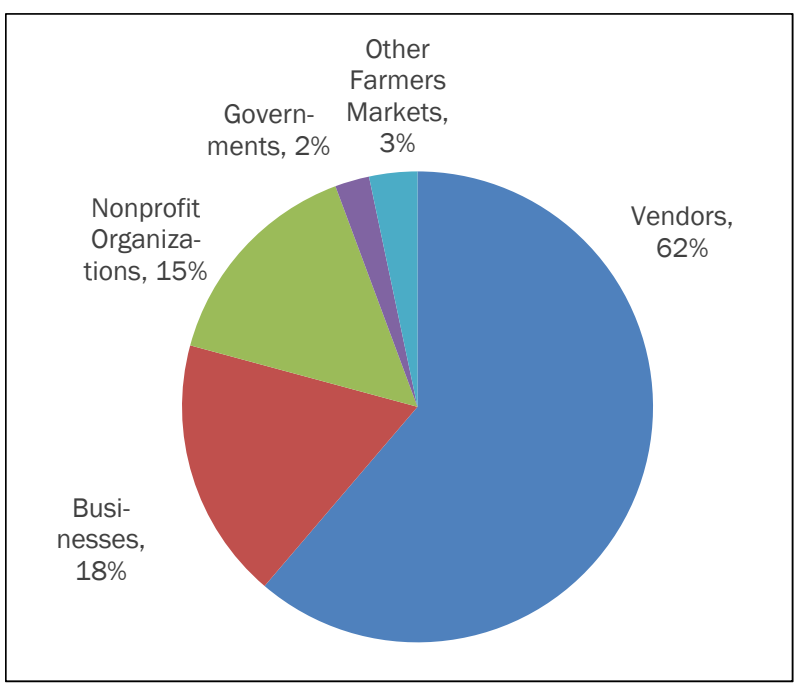


Table 1. Distribution of Posts $(N=6,369)$ by Post Owner, Posting Intentions and Media Type

\begin{tabular}{|c|c|c|c|c|c|c|}
\hline \multirow{2}{*}{ Classification } & \multirow{2}{*}{ Categories } & \multicolumn{5}{|c|}{ Post Owners (\%) } \\
\hline & & CPFM & Customer & Vendor & Others & Total \\
\hline \multirow{5}{*}{ Posting Intention } & Announcement & 63.7 & 0.8 & 32.9 & 2.6 & 100.0 \\
\hline & Inviting Engagement & 76.3 & 10.5 & 10.8 & 2.3 & 100.0 \\
\hline & Market Experience & 36.8 & 38.2 & 24.9 & 0.1 & 100.0 \\
\hline & Inquiry Market Information & 2.5 & 93.5 & 4.0 & 0.0 & 100.0 \\
\hline & Share & 84.0 & 7.6 & 6.7 & 1.7 & 100.0 \\
\hline All posts & & 60.5 & 12.7 & 24.8 & 2.0 & 100.0 \\
\hline
\end{tabular}

a Total by rows. Columns might not add up to $100 \%$ due to rounding.

CPFM (63.7 percent), vendors (32.9 percent), and others (2.6 percent) posted Announcements on CPFM's Facebook. We further examined the contents of the Announcements and found that CPFM posted general market-day and product information (e.g., post 1) as well as highlighted specific vendors to increase excitement and generate exposure for what will be the market's attractions that week (e.g., post 2). This indicates that CPFM's Facebook page was serving not only as a marketing channel for farmers markets, but also as a marketing channel for vendors and as a public bulletin (e.g., post 10) for the community. The results of analyzing the posting intentions suggests that the major role of CPFM's Facebook was as a marketing platform to disseminate information about market day and hours, products, events, and community-related messages (e.g., posts 1-4). In terms of communication between customers and CPFM, similar to other businesses' Facebook pages (Cvijikj \& Michahelles, 2011; Ramsaran-Fowdar \& Fowdar, 2013), customers were most likely to interact with businesses on Facebook for product and service information: 93.5 percent of Inquiring Market Information posts belonged to customers, who most often asked questions regarding operating hours and location, but also asked for individual vendor's attendance (e.g., post 8). The owner of the CPFM Facebook page posted most of its messages with the intent to engage fans: Inviting Engagement (76.3 percent) and Share (84.0 percent). Customers (38.2 percent), CPFM (36.8 per-

Table 2. Distribution of Posts $(N=6,369)$ by Post Owner, Posting Intention, and Media Type

\begin{tabular}{|c|c|c|c|c|c|c|}
\hline \multirow{2}{*}{ Classification } & \multirow{2}{*}{ Categories } & \multicolumn{5}{|c|}{ Media Type (\%) } \\
\hline & & Text-only & Link & Photo & Video & Total $^{\mathrm{a}}$ \\
\hline \multirow{4}{*}{ Post Owners } & Farmers Market & 48.7 & 33.9 & 16.5 & 0.9 & 100.0 \\
\hline & Customer & 88.2 & 6.1 & 5.7 & 0.0 & 100.0 \\
\hline & Vendor & 81.2 & 7.3 & 11.1 & 0.3 & 100.0 \\
\hline & Others & 44.0 & 48.0 & 1.6 & 6.4 & 100.0 \\
\hline \multirow{5}{*}{ Posting Intention } & Announcement & 70.1 & 19.9 & 9.6 & 0.4 & 100.0 \\
\hline & Inviting Engagement & 53.0 & 34.5 & 11.8 & 0.7 & 100.0 \\
\hline & Market Experience & 61.6 & 8.8 & 29.1 & 0.4 & 100.0 \\
\hline & Inquiry Market Information & 99.1 & 0.3 & 0.6 & 0.0 & 100.0 \\
\hline & Share & 13.2 & 62.7 & 21.0 & 3.1 & 100.0 \\
\hline All posts & & 61.7 & 24.1 & 13.5 & 0.7 & 100.0 \\
\hline
\end{tabular}

a Total by rows. Columns might not add up to $100 \%$ due to rounding. 
cent), and vendors (24.9 percent) all posted enthusiastically about market experiences. Other than being a marketing platform, the messages for Announcement purposes demonstrated that the CPFM Facebook page was a hub: the CPFM and others posted their announcements of community events and news (e.g., Post 3) and the Facebook page acted as a public bulletin board to disseminate information for local community, businesses, and nonprofit organizations.

Table 2 is a cross-tab of media type by post owner and posting intention. For the media type classification, the major type used on CPFM's Facebook page were Text-Only posts (61.7 percent); the remaining were Link (24.1 percent), Photo (13.5 percent), and Video (0.7 percent). The relationship between post owner and media type show that customers ( 88.2 percent) and vendors (81.2 percent) mainly posted Text-Only information. Others, including local businesses and organizations, mainly used Text-Only messages (44.0 percent) and Links (47.2 percent). CPFM's posts were more diverse when it comes to media (48.7 percent for Text-Only, 32.1 percent for Link and 16.5 percent for Photos). This suggests that CPFM aimed to use Facebook as a marketing tool by utilizing a variety of media opportunities to attract and engage customers and vendors.

The cross-tab by posting intention and media type shows that about 70.1 percent of announcements and 99.1 percent of Inquiring Market Information were Text-Only messages, making the accessibility of this information easy and efficient. Shares (63.1 percent) and Inviting Engagement (34.1 percent) had a higher percentage of Links included in the posts, while one-third of Market Experience posts included Photos. The result is consistent with other social media marketing research (Cvijikj et al., 2011; He et al., 2013) in terms of media type, and suggests that the CPFM used its Facebook page efficiently and effectively as a communication tool to disseminate information and engage customers and vendors.

Next, we examined variations of posting

Figure 5. Distribution of Posts $(N=6,369)$ by Day of the Week Corresponding to Market Days

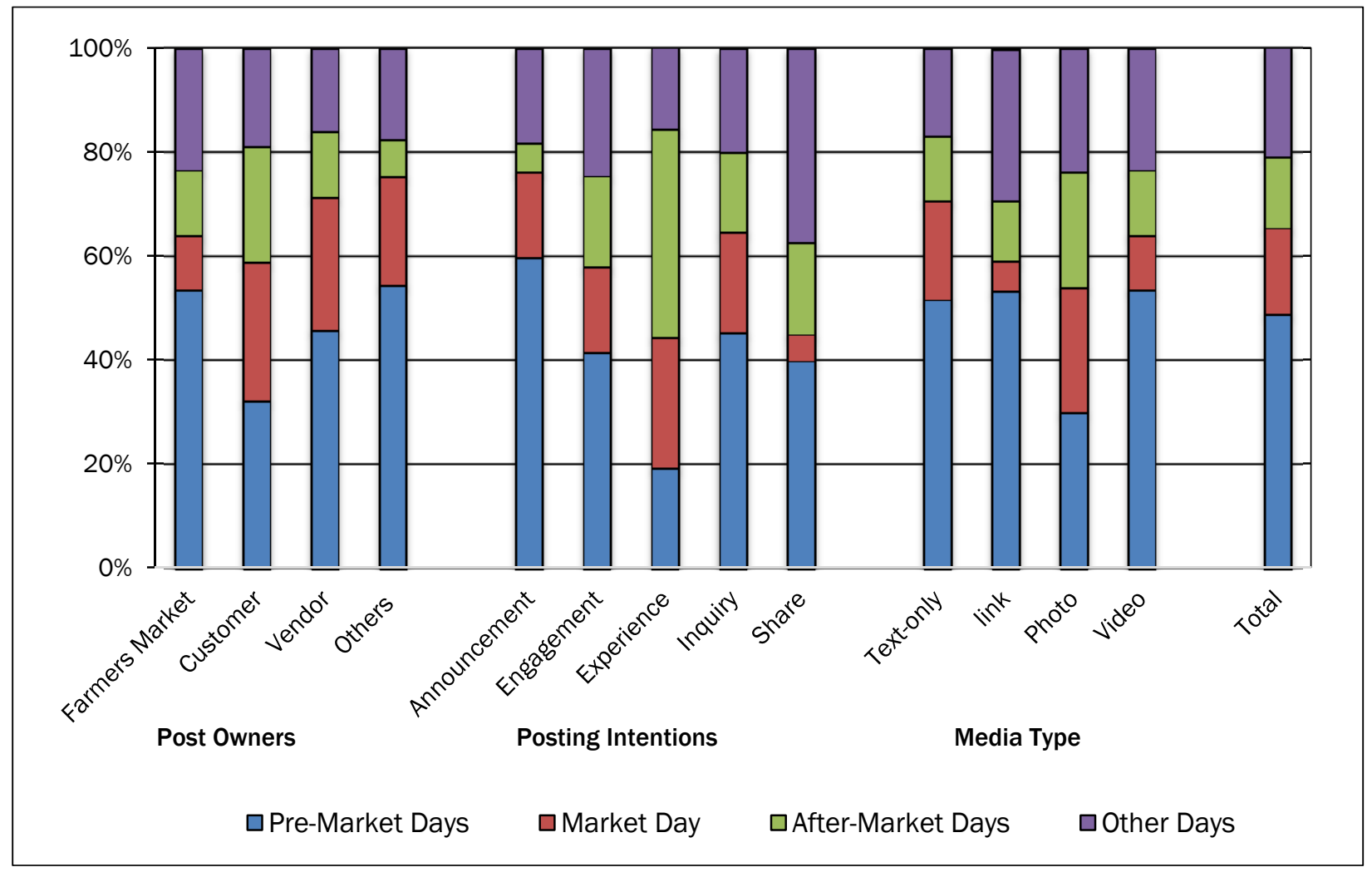


intensity on CPFM's Facebook page by day of the week. They were further grouped by Pre-market Days (Thursday and Friday), Market Day (Saturday), After-market Days (Sunday and Monday), and Other Days (Tuesday and Wednesday). In general, about 66 percent of the messages were posted on Pre-market Days and Market Days. Fourteen percent of the posts were on After-Market Days and 21 percent were posted on Other Days. Figure 5 illustrates posting intensity by different post classifications. The distribution of posts by day of the week shows that CPFM's Facebook page functioned as an advertising outlet on Pre-market days in an attempt to attract customer attention. Over half of CPFM's posts were on Pre-market days, informing customers about what to expect at the market that Saturday, while the Market Day itself has only 16.9 percent of the overall posts (since customers and vendors might be physically at the market). Our further examination of posting intensity and posting intention found that the majority of Announcements (76 percent) and Inquires for Market Information (64 percent) were posted on Pre-market Days or Market Day. In contrast, the market experience posts were published on Market Day and After-market Days (65 percent). In terms of post owners, CPFM posted more on Pre-market Days (54 percent), making various announcements. This suggests that CPFM and vendors used the CPFM Facebook page to reach customers right before market day.

To measure the interaction and engagement of fans and CPFM on the Facebook page, posts were labeled as engaged posts based on the attention they received (likes, comments, and shares) and the degree of engagement (Equation 1). A chi-squared analysis was applied to test the variations between different types of posts for each classification (post owner, posting intention, media type, and posting intensity). The distribution of the percentage of engaged posts is listed in Table 3. In general, 83.1 percent of posts become engaged (receiving likes,

Table 3. Distribution of Engaged Posts ( $N=6,369$ and Degree of Engagement by Post Classifications

\begin{tabular}{|c|c|c|c|c|}
\hline Classifications & Categories & $\begin{array}{c}\% \text { of engaged } \\
\text { posts }^{a}\end{array}$ & $\begin{array}{l}\text { Average degree } \\
\text { of engagement }^{b}\end{array}$ & $\begin{array}{l}\text { Standard degree } \\
\text { of engagement }\end{array}$ \\
\hline \multirow{4}{*}{ Post Owner } & CPFM & 90.5 & 0.0017 & 0.0029 \\
\hline & Customer & 76.9 & 0.0007 & 0.0013 \\
\hline & Vendor & 69.4 & 0.0005 & 0.0010 \\
\hline & Other & 71.2 & 0.0005 & 0.0007 \\
\hline \multirow{5}{*}{ Posting Intention } & Announcement & 84.0 & 0.0011 & 0.0019 \\
\hline & Inviting Engagement & 85.6 & 0.0024 & 0.0044 \\
\hline & Market Experience & 77.2 & 0.0012 & 0.0023 \\
\hline & Inquiry Marketing Info & 89.2 & 0.0007 & 0.0012 \\
\hline & Share & 80.8 & 0.0012 & 0.0020 \\
\hline \multirow{4}{*}{ Media Type } & Text-only & 82.2 & 0.0012 & 0.0025 \\
\hline & Link & 82.0 & 0.0009 & 0.0016 \\
\hline & Photo & 90.5 & 0.0019 & 0.0031 \\
\hline & Video & 78.3 & 0.0009 & 0.0011 \\
\hline \multirow{4}{*}{ Day in Week } & Pre-market Days & 84.1 & 0.0010 & 0.0019 \\
\hline & Market Days & 84.8 & 0.0012 & 0.0023 \\
\hline & After-market Days & 81.8 & 0.0017 & 0.0035 \\
\hline & Other Days & 86.7 & 0.0014 & 0.0026 \\
\hline Average & & 83.1 & 0.0012 & 0.0024 \\
\hline
\end{tabular}

a Pearson chi-squared tests with $p$ value $<0.01$ for different types of posts in each classification

${ }^{b}$ One-way ANOVA tests with $p$ value $<0.01$ for different types of posts in each classification 
comments, and/or shares). The chi-squared test results show that there are significant differences between the engaged posts and non-engaged posts for types of posts for each classification. In term of post owner classification, CPFM (90.5 percent)'s posts received more attention overall, which may be suggestive of CPFM's efforts to create opportunities for using the page and for enhancing engagement using various types of posts. For the posting intention classification, Inquiry Market Information (89.2 percent) received the most attention. Customer posts categorized as inquiries elicited the most comments, suggesting that customers were quick to receive responses to questions they posed. Active engagement is a sure way to encourage fans to continue participating on CPFM's Facebook page. Of the media type classification, Photos ( 90.5 percent) received the most attention from fans. The majority of interactions with the photos were likes. This finding is consistent with the results of other studies (Cvijikj et al., 2011).

For degree of engagement, we conducted oneway ANOVA tests to explore the variations between different types of posts for each classification. The results indicate that the average degree of engagement is significantly different between post types for each classification (Table 3). For post owner classification and media type classification, the higher the percentage of engaged posts, the higher the degree of engagement. However, under the classification of posting intention, Inquiry Market Information posts received the lowest degree of engagement, while the percentage of engaged posts were the highest. This is because customers were able to receive the answers to their questions fairly quickly, and there was no longer a need for interaction on the post. Furthermore the purpose of Inviting Engagement posts is to invite discussions and solicit answers. It is not surprising that the engagement ratio of Inviting Engagement posts was twice that of other types of posts due to the back and forth among the CPFM and its fans. For posting intensities, the engagement ratio on days other than Pre-market Days and Market Day was higher. This suggests that CPFM made more of an effort to engage fans and build a relationship with the customers when there was not intense posting of announcements and market experiences on the wall.

\section{Conclusions}

Social media reach people on a larger scale and a faster speed than previous communication media have allowed. Social media platforms have been adopted by small and large businesses alike for marketing and communication purposes with the standardized format, low need for special technical skills, and low cost. Farmers markets, being small businesses, have taken advantage of Facebook as a marketing channel. Using Cedar Park Farmers Market as a case study, the data supports the conclusion that CPFM's Facebook page is an efficient and effective marketing platform for both the farmers market and its vendors due to the dynamic characteristics of products and events at the farmers market. CPFM used the header and profile (photos, tabs, and links) at the top of its Facebook page to highlight its market and provide the basic and fixed market operation information. At the same time, CPFM used its Facebook page to publish market operation information, advertise products and vendors, and promote upcoming events, all before each Market Day. Customers also posted their inquiries before Market Day and got quick responses from the CPFM. After the Market Day, customers, vendors, and the CPFM itself all posted their market experiences on the page. During the Other Days, CPFM invited fans to engage in various topics of interest, such as food safety and nutrition (e.g., Post 5), sharing recipes and resources (e.g., Post 9), etc. This strategy successfully attracted and retained customers and vendors. As a result, the number of fans of CPFM's Facebook page has increased steadily since the page was created (Figure 1). In addition to its function as a marketing tool, Facebook is a cyber community (Zhang, Tang, \& Leung, 2011) for people to gather, interact, develop friendships, and share information, photos, experiences, and more. Farmers markets are also social hubs, both physically and symbolically. The same people who like to get together and talk during the farmers markets might also like to share ideas during the 
rest of the week. Facebook provides a convenient forum for "fans" of farmers markets to get together online. Our study found that the CPFM Facebook page acted as a hub to provide a platform that allows natural sharing of ideas, thoughts, and concerns, and facilitates people's engagement in conversations of various topics. On CPFM's Facebook page, the market organizer announced information for the local community, engaged fans with community issues, and shared community information, as well as allowing community members to post their messages on CPFM's Facebook page. The Facebook page works as a hub, reflecting the peripheral functions of the actual market experience as discussed in previous sections.

\section{Management and Research Implications}

With an increasing number of food consumers utilizing various forms of social media to identify, research, and buy local foods, farmers markets and other local food retailers (e.g., food hubs, CSAs) can benefit from social media for relationship marketing. Communicating fresh and imaginative content employing social media can affect both long-term (e.g., CSA subscriptions) and more immediate decisions (e.g., whether to visit and what to purchase at a farmers market today) concerning food purchases and preparation. The integration and targeting of social media offers local food providers new and effective opportunities for branding, sales promotions, and loyalty and relationship development. Therefore farmers markets that utilize Facebook need to understand who their fans are and how and when they interact and engage their farmers markets' page. The content that is posted should be continuously refreshed and emphasize the benefits to consumers and communities associated with sustainable local food. It is also important that farmers markets regularly respond to reviews posted on their Facebook page since reputation is critical and a portion of negative reviews can become positive if they secure a response. Markets should further consider providing customers with take-home information with every purchase (e.g., labeling, business cards) that includes their Facebook web address.
Local food providers should also consider employing social media as a means of collecting data on their customers and identifying their actual behavior. Social media provide new platforms for researchers to observe directly the interaction of different roles at farmers markets through their dialogues, likes, and what they share, without any interruption. This works as a method of cyber ethnography. In addition, the Facebook Graph API Explorer provides a "friendship" graph to visualize social networks (Cross, 2011). While previous studies have attempted to understand the social networks related to farmers markets, there is no clear picture of how this network is connected, especially for local food access, such as from farm to farmers market. Since organization-level fans provide their business description and locations on Facebook, the cyber social network could be mapped to a spatial social network in reality. This might not be possible through the direct observation and interview methods of observing physical farmers markets.

\section{Limitations and Future Work}

A limitation of this study was the lack of access (due to privacy issues) to the CPFM's Facebook page actual use data, such as traffic count, impression, demographics of fans, active fans, and number of people who browsed the page on a particular day. This made some measurements problematic. For example, the degree of engagement (Equation (1)) will decrease as the number of fans increases over time since we used the total number of fans as the denominator. As the page owner, CPFM could gather the number of fans on the page or the number of people who saw the post on a particular day. Utilizing these two variables as the denominator in Equation (1) would make the measurement of the degree of engagement more precise and accurate because these two variables measure the actual traffic count of the Facebook page on that particular day. We suggest that farmers market Facebook page owners track their page's visits and fan demographics to inform an effective marketing strategy to disseminate timely information and engage customers, vendors, and community members. In addition, scholars and practitioners realize the population on social media 
does not reflect the population in reality. Similar to other social space, social media spaces might reproduce cliques, foster inward referencing, and generally fail to reach out across diverse groups. For example, a typical user of Facebook tends to be young and female compared to the total population (Sage, 2014). Moreover, not all people interact on farmers market Facebook pages. Our study successfully detected the interaction between farmers market customers and vendors (e.g., Post 5). However, unlike the findings from physical markets (Gerbasi, 2006), we did not find any conversations among vendors on CPFM's Facebook page; it might be unnecessary for two vendors to have a conversation on a third party's page. Another limitation is the semi-manual coding methods used to categorize the posts that could result in a misclassification of posts and post owners. For example, if the vendors or businesses used their personal profile instead of their business page to join CPFM's Facebook page, they were categorized as customers, not organizations. For future studies, data-mining tools will need to be introduced for message classification, topic detections and content analysis. This study is the author's first attempt to explore how farmers markets use Facebook. The study subject, CPFM, is a large, year-round market residing in an urban area. Fans are very active on its page. There are another 2,000 farmers markets on Facebook who are large and small, seasonal or year-round, urban or rural, patronized by affluent customers or those from low-income communities. Future research will extend the subjects from CPFM to all farmers markets reporting their Facebook page in USDA's Farmers Market Directory to understand more about how farmers market use social media.

\section{References}

Abel, J., Thomson, J., \& Maretzki, A. (1999). Extension's role with farmers' markets: Working with farmers, consumers, and communities. Journal of Extension, 37(5), 150-165.

Alia, K. A., Freedman, D. A., Brandt, H. M., \& Browne, T. (2013). Identifying emergent social networks at a federally qualified health center-based farmers' market. American Journal of Community Psychology, 53(3-4), 335-345. http://dx.doi.org/10.1007/s10464-013-9616-0

Andreatta, S., \& Wickliffe, W. (2002). Managing farmer and consumer expectations: A study of a North Carolina farmers market. Human Organization, 61(2), 167-176.

Boyd, D. M., \& Ellison, N. B. (2007). Social network sites: Definition, history, and scholarship. Journal of Computer-Mediated Communication, 13(1), 210-230. http://dx.doi.org/10.1111/j.10836101.2007.00393.x

Brown, A. (2001). Counting farmers markets. Geographical Review, 91(4), 655-674. http://dx.doi.org/10.2307/3594724

Brown, C., \& Miller, S. (2008). The impacts of local markets: A review of research on farmers markets and community supported agriculture (CSA). American Journal of Agricultural Economics, 90(5), 1298-1302. http://dx.doi.org/10.1111/j.14678276.2008.01220.x

Cedar Park Farmers Market [CPFM]. (n.d.). Cedar Park Farmers Market [Facebook page]. Retrieved December 22, 2013, from https://www.facebook. com/CedarParkFM?ref $=$ br tf

Conner, D., Colasanti, K., Ross, R. B., \& Smalley, S. B. (2010). Locally grown foods and farmers markets: Consumer attitudes and behaviors. Sustainability, 2(3), 742-756. http://dx.doi.org/10.3390/su2030742

Cowee, M. W., Curtis, K. R., \& Gatzke, H. (2009). Marketing farmers' markets: Ideas for market vendors \& managers in Nevada. Reno, Nevada: University of Nevada Cooperative Extension.

Cross, S. (2011). Introducing the Graph API Explorer. Retrieved December 22, 2013, from https://developers.facebook.com/blog/post/517

Cummings, H., Kora, G., \& Murray, D. (1998). Farmers' markets in Ontario and their economic impact. Ontario, Canada: University of Guelph.

Cvijikj, I. P., \& Michahelles, F. (2011). Understanding social media marketing: A case study on topics, categories and sentiment on a Facebook brand page. Proceedings of the 15th International Academic MindTrek Conference: Envisioning Future Media Environments, 175-182. http://dx.doi.org/10.1145/2181037.2181066 
Cvijikj, I. P., Spiegler, E. D., \& Michahelles, F. (2011). The effect of post type, category and posting day on user interaction level on Facebook. Privacy, Security, Risk and Trust (PASSAT) and 2011 IEEE Third Inernational Conference on Social Computing (SocialCom), 810-813. http://dx.doi.org/10.1109/ PASSAT/SocialCom.2011.21

Facebook. (n.d.a). Popular features. Retrieved December 22, 2013, from https://www.facebook.com/help/ $\underline{393277774048285}$

Facebook. (n.d.b). Page insights. Retrieved December 22, 2013, from https://www.facebook.com/help/ 390967410974308 ? $\mathrm{sr}=1$ \&query $=$ insights\&sid $=03 \mathrm{O}$ BXPjLFsRSdnUJh

Farmer, J. R., Chancellor, C., Gooding, A., Shubowitz, D., \& Bryant, A. (2011). A tale of four farmers markets: Recreation and leisure as a catalyst for sustainability. Journal of Park and Recreation Administration, 29(3), 11-23.

Feagan, R. B., \& Morris, D. (2009). Consumer quest for embeddedness: A case study of the Brantford Farmers' Market. International Journal of Consumer Studies, 33(3), 235-243. http://dx.doi.org/10.1111/ j.1470-6431.2009.00745.x

Francis, M., \& Griffith, L. (2011). The meaning and design of farmers' markets as public space: An issue-based case study. Landscape Journal, 30(2), 261-279. http://dx.doi.org/10.3368/li.30.2.261

Gerbasi, G. T. (2006). Athens farmers' market: Evolving dynamics and hidden benefits to a southeast Ohio rural community. Focus on Geography, 49(2), 1-6. http://dx.doi.org/10.1111/j.19498535.2006.tb00160.x

Griffin, M. R., \& Frongillo, E. A. (2003). Experiences and perspectives of farmers from Upstate New York farmers' markets. Agriculture and Human Values, 20(2), 189-203. http://dx.doi.org/10.1023/A:1024065526440

Guthrie, J., Guthrie, A., Lawson, R., \& Cameron, A. (2006). Farmers' markets: The small business counter-revolution in food production and retailing. British Food Journal, 108(7), 560-573. http://dx.doi.org/10.1108/00070700610676370

He, W., Zha, S., \& Li, L. (2013). Social media competitive analysis and text mining: A case study in the pizza industry. International Journal of Information Management, 33(3), 464-472. http://dx.doi.org/10.1016/j.ijinfomgt.2013.01.001
Hergesheimer, C., \& Kennedy, E. H. (2010). Farmers markets, local food systems and the social economy: $A$ thematic literature review. Port Albern, British Columbia: Canadian Centre for Community Renewal.

Hinrichs, C. C., Gillespie, G. W., \& Feenstra, G. W. (2004). Social learning and innovation at retail farmers' markets. Rural Sociology, 69(1), 31-58.

Holloway, L., \& Kneafsey, M. (2000). Reading the space of the farmers' market: A case study from the United Kingdom. Sociologia Ruralis, 40(3), 285-299. http://dx.doi.org/10.1111/1467-9523.00149

Hunt, A. R. (2007). Consumer interactions and influences on farmers' market vendors. Renewable Agriculture and Food Systems, 22(1), 54-66. http://dx.doi.org/10.1017/S1742170507001597

Jussila, J. J., Kärkkäinen, H., \& Aramo-Immonen, H. (2014). Social media utilization in business-tobusiness relationships of technology industry firms. Computers in Human Behavior, 30, 606-613. http://dx.doi.org/10.1016/j.chb.2013.07.047

Kaplan, A. M., \& Haenlein, M. (2010). Users of the world, unite! The challenges and opportunities of social media. Business Horizons, 53(1), 59-68. http://dx.doi.org/10.1016/j.bushor.2009.09.003

Kaufman, J. L. (2004). Introduction. Journal of Planning Education and Research, 23(4), 335-340. http://dx.doi.org/10.1177/0739456X04264897

Keckley, P. H., \& Hoffmann, M. (2010). Social networks in bealth care: Communication, collaboration and insights. Washington, D.C.: Deloitte Development.

Khan, M. L., \& Boehmer, J. (2013, October). Small business use of Facebook for marketing: The case of a family owned Mediterranean restaurant. Paper presented at the 78th Annual Association for Business Communication International Conference, New Orleans, Louisiana.

La Trobe, H. (2001). Farmers' markets: Consuming local rural produce. International Journal of Consumer Studies, 25(3), 181-192. http://dx.doi.org/10.1046/j.14706431.2001.00171.x

Leung, R., Schuckert, M., \& Yeung, E. (2013). Attracting user social media engagement: A study of three budget airlines Facebook pages. In L. Cantoni \& Z. Xiang (Eds.), Information and communication technologies in tourism 2013: Procedings of the International Conference in Innsbruck, Austria, January 22-25, 2013 (pp. 195206). Berlin, Germany: Springer Berlin Heidelberg. http://dx.doi.org/10.1007/978-3-642-36309-2 17 
Luke, K. (2009). Marketing the new-fashioned way: Connect with your target market through social networking sites. Journal of Financial Planning, 22(Nov./Dec. Practice Management Solutions), 18-19.

Lyson, T. A., Gillespie, G. W., \& Hilchey, D. (1995). Farmers' markets and the local community: Bridging the formal and informal economy. American Journal of Alternative Agriculture, 10(3), 108-112. http://dx.doi.org/10.1017/S0889189300006251

Madison, D. (2002). Farmers' markets: Making big connections. Phi Kappa Phi Forum, 82(3), 15-18.

McGrath, M. A., Sherry Jr, J. F., \& Heisley, D. D. (1993). An ethnographic study of an urban periodic marketplace: Lessons from the Midville farmers' market. Journal of Retailing, 69(3), 280-319. http://dx.doi.org/10.1016/0022-4359(93)90009-8

Morris, C., \& Buller, H. (2003). The local food sector: A preliminary assessment of its form and impact in Gloucestershire. British Food Journal, 105(8), 559-566. http://dx.doi.org/10.1108/00070700310497318

Oberholtzer, L., \& Grow, S. (2003). Producer-only farmers' markets in the Mid-Atlantic region: A survey of market managers. Arlington, Virgina: Henry A. Wallace Center for Agricultural and Environmental Policy at Winrock International.

Palmer, A., \& Koenig-Lewis, N. (2009). An experiential, social network-based approach to direct marketing. Direct Marketing: An International Journal, 3(3), 162176. http://dx.doi.org/10.1108/17505930910985116

Parsons, A. (2013). Using social media to reach consumers: A content analysis of official Facebook pages. Academy of Marketing Studies Journal, 17(2), 27-36.

Payne, T. (2002). U.S. farmers' markets 2000: A study of emerging trends. Journal of Food Distribution Research, 33(1), 173-175. http://purl.umn.edu/27625

Rafaeli, S., \& Sudweeks, F. (1997). Networked interactivity. Journal of Computer-Mediated Communication, 2(4). http://dx.doi.org/10.1111/j.10836101.1997.tb00201.x

Ramsaran-Fowdar, R. R., \& Fowdar, S. (2013). The implications of Facebook marketing for organizations. Contemporary Management Research, 9(1), 73-84. http://dx.doi.org/10.7903/cmr.9710

Sadler, R. C., Clark, M. A. R., \& Gilliland, J. A. (2013). An economic impact comparative analysis of farmers' markets in Michigan and Ontario. Journal of Agriculture, Food Systems, and Community Development, 3(3), 61-81.

http://dx.doi.org/10.5304/jafscd.2013.033.009

Sage, A. (2013). The Facebook platform and the future of social research. In C. A. Hill, E. Dean \& J. Murphy (Eds.), Social media, sociality, and survey research (pp. 87-106). Hoboken, New Jersey: John Wiley. http://dx.doi.org/10.1002/9781118751534.ch4

Sanderson, K., Gertler, M., Martz, D., \& Mahabir, R. (2005). Farmer's markets in North America: A background document. Saskatoon, Saskatchewan, Canada: Community-University Institute for Social Research.

Smithers, J., Lamarche, J., \& Joseph, A. E. (2008). Unpacking the terms of engagement with local food at the Farmers' Market: Insights from Ontario. Journal of Rural Studies, 24(3), 337-350. http://dx.doi.org/10.1016/j.jrurstud.2007.12.009

U.S. Department of Agriculture [USDA]. (n.d.a). Farmers markets directory search. Retrieved January 15, 2014 , from http://search.ams.usda.gov/farmersmarkets/

USDA (n.d.b). National count of farmers market directory listing graph: 1994-2014. Retrieved January 15, 2014, from http://www.ams.usda.gov/AMSv1.0/ ams.fetchTemplateData.do? template $=$ TemplateS\&l eftNav $=$ WholesaleandFarmersMarkets\&page $=W F$ MFarmersMarketGrowth\&description $=$ Farmers $\% 2$ 0Market $\% 20$ Growth

Vivek, S. D., Beatty, S. E., \& Morgan, R. M. (2012). Customer engagement: Exploring customer relationships beyond purchase. The Journal of Marketing Theory and Practice, 20(2), 122-146. http://dx.doi.org/10.2753/MTP1069-6679200201

Zhang, Y., Tang, L. S. T., \& Leung, L. (2011). Gratifications, collective self-esteem, online emotional openness, and traitlike communication apprehension as predictors of Facebook uses. Cyberpsychology Behavior and Social Networking, 14(12), 733-739. http://dx.doi.org/10.1089/cyber.2010.0042 